\title{
Tuberculosis of the oesophagus
}

\author{
A. R. F A H M Y, R. GUINDI, AND A. FAR ID \\ From the Departments of Surgery, Thoracic Surgery, and Pathology, Ain Shams University, Cairo, Egypt
}

\begin{abstract}
A case of primary tuberculosis of the oesophagus is presented ; the patient was successfully treated by oesophagectomy. The condition, being rare, has stimulated the authors to review the literature concerning primary and secondary oesophageal tuberculosis. The history, modes of infection, the pathology, clinical picture, diagnosis, investigations, and methods of treatment are discussed. In contradistinction to the secondary disease, which is terminal, primary tuberculosis of the oesophagus is a curable disease with a fairly good prognosis. The case report shows that the surgeon should pay careful attention to the site of the anastomosis; otherwise post-operative stricture can develop. Even this responds well to dilatations and the patient can regain normal health.
\end{abstract}

The first antemortem diagnosis of tuberculosis of the oesophagus was made in 1907 by Schrötter ; and the first post-mortem report was by Denonvillers in 1837 (Terracol and Sweet, 1958).

Until 1950 no case is on record of primary tuberculosis of the oesophagus; all the reported cases have suggested that tuberculosis becomes established in the oesophagus by one of the following routes:

(1) Swallowed sputum in patients having advanced open pulmonary tuberculosis, especially when they are undernourished and have stagnation of swallowed sputum proximal to an oesophageal stricture (Heimendinger, Fruhling, and Klotz, 1949). We note that, whereas tuberculosis of the intestine is common, the disease hardly ever involves the oesophagus. We suggest that the difference may be in the blood supply, lymph drainage, and mucous secretion.

(2) Direct continuity, e.g., from Pott's disease of the spine (Maillet, 1960), from an adherent tuberculous cavity of the lung or from tuberculous lymph nodes in the mediastinum (Roget, Jaudel, Beaudoing, Valois, and Gilbert, 1960 ; Montandon, 1964).

(3) Retrograde lymphatic spread. The oesophagus drains into the peribronchial, subcarinal, and paratracheal lymph nodes and the glands described by Rouvière which are found between the oesophagus and the aorta near to the inferior pulmonary veins. The pathological changes produced by this type of spread are referred to as 'para-oesophageal tuberculosis' and they are responsible for such lesions as traction diverticulae of the oesophagus (Doesel, 1960; Roget et al.,
$1960)$ and fistulous communication, especially with $\overrightarrow{0}$ the left main bronchus. This process was re--o sponsible for the oesophago-pleural fistula described by Warembourg, Delacroix, Pauchant, and Sergent (1959) after pneumonectomy for tuberculosis; the fistula was repaired by pre-음 thoracic oesophagoplasty.

(4) Blood-borne disease is possible but has no been reported.

The above routes of infection are responsible for secondary disease of the oesophagus; but primary tuberculosis is rare ; cases have been reported by Baron, Venisse, and Legal (1961), and by Audouin and Poulain (1950). The term 'primary' tuberculosis of the oesophagus is used to signify that the patient has no evidence of the disease elsewhere.

Whatever the pathogenesis may be there are three naked-eye forms of the disease-the hyper-o trophic, granular, and ulcerative types. The latter? is the most commonly seen and the granular is theo rarest. The ulcerative type may present as solitary. or multiple ulcers, occurring in the proximal thirdos of the oesophagus, and the naked-eye appearancon and the histological picture do not differ from tuberculous ulceration elsewhere in the body. The hypertrophic type usually affects the middle third and may involve a long segment of the oeso은 phagus. In its naked-eye appearance, development and microscopy it behaves like the hypertrophic form of the disease in the ileo-caecal region, with the result that the lumen of the oesophagus be comes obstructed. The granular form has ? velvety appearance ; the surface of the lesion is greyish in colour. 
Clinically, the symptoms depend upon the degree of pathological involvement. Pain and dysphagia are two cardinal subjective findings. Pain is the more pronounced symptom if there is ulceration. It is felt in the throat and referred to the ears and often involves the upper part of the oesophagus; it is also experienced in the retrosternal region and radiates to the back. The pain is usually continuous and is increased by swallowing, even of saliva. Dysphagia is progressive and is like that of cancer of the oesophagus, being first to solids, then to semisolids, and finally to liquids.

Barium examination of the oesophagus shows diminished motility and stricture of the area affected. Lüdin (1947) has described the radiological appearances in detail.

At oesophagoscopy the appearance depends on the type of lesion present ; the mucosa is pale and there may be tubercles scattered here and there. Biopsy may be conclusive. Pretzman (1942) described a case of tuberculosis of the oesophagus diagnosed at oesophagoscopy.

In addition to affection of the general condition due to starvation and toxaemia, tuberculosis of the oesophagus may present itself on account of one of the complications such as traction diverticulum (Kragh, 1922), oesophago-bronchial fistula (Montandon, 1964), oesophago-pleural fistula (Warembourg et al., 1959), oesophagocutaneous fistula (Lawson, 1949), right recurrent nerve paralysis (Calvet, Coll, and Son-Qui, 1961), left recurrent laryngeal nerve paralysis or malignant change with tuberculous disease (Aubin, 1943). Bacteriological and cytological examinations of the oesophageal washings and histological examination of a biopsy specimen are the two conclusive points in diagnosis.

With the sscondary type of oesophageal tuberculosis the prognosis is bad and the disease is terminal. With primary tuberculosis, especially with the hypertrophic type, the prognosis is good when properly managed.

Antituberculosis treatment must be given. Surface anaesthetics may be given by mouth to relieve the pain, as also may antispasmodics. In the hypertrophic type causing obstructive dysphagia, especially if there is no other active tuberculous focus, oesophagectomy should be done, with restoration of the continuity of the gullet (Jeanne, 1948 ; Audouin and Poulain, 1950).

\section{CASE REPORT}

S. A., a girl aged 15 years, was admitted to Demeradash Hospital, Cairo, on 25 April 1967. She had been complaining of progressive dysphagia for three months prior to her admission. The patient gave no history of tuberculosis or of any other debilitating disease. She was underweight and cachectic. The blood picture showed secondary anaemia and the leucocyte count was $8,000 /$ c.mm. with relative lymphocytosis. Radiologically the lung fields were normal and a barium swallow showed a stricture involving practically the whole oesophagus. Oesophagoscopy revealed a small oesophageal pouch just below the cricopharyngeus, which was dilated and lined with healthy mucosa, and this led to a long narrow stricture. Tuberculin tests were positive.

The girl had no history of having swallowed caustic. Her general condition was improved by small repeated blood transfusions, and amino acid and multivitamin infusions given over two weeks. She could only swallow fluids. Her serum electrolytes were corrected, and she was operated upon on 11 May 1967. Laparotomy was first performed through a left upper paramedian incision, and exploration revealed nothing abnormal. The stomach was mobilized and the hiatus freed and dilated. The abdomen was closed. The patient was turned on to the left side and the right chest was opened through the bed of the fifth rib. The mediastinal pleura, lung, and mediastinal lymph nodes were normal and free. The mediastinal pleura was incised and the vena azygos was cut between two ligatures. The oesophagus was contracted and much thickened; it had an irregular surface and felt as firm as cartilage. The lesion extended almost to the apex of the chest. After mobilization of the thoracic oesophagus, the stomach was brought up into the thoracic cavity. The diseased part of the oesophagus and the cardiac end of the stomach were resected; the stomach was anastomosed to the thoracic oesophagus at the top of the chest. The oesophagus at the site of the anastomosis, though of reasonable calibre, was thick and firm and its wall was not healthy. The chest was closed with a tube connected to an underwater seal; this was removed after three days. The post-operative course was stormy, but the patient was discharged swallowing reasonably well. Swallowing improved for six months postoperatively, and then she began to get dysphagia again, and for this she is treated by frequent endoscopic dilatations. She has gained weight, is not anaemic, and has gone back to school. The correct diagnosis was made after histopathology; the sections show hypertrophic oesophageal tuberculosis.

\section{REFERENCES AND BIBLIOGRAPHY}

Aubin, V. M. (1943). Un cas de tuberculose hypertrophique de l'oesophage avec dégénérescence cancéreuse. Soc. de Laryng ol. Hôp. de Paris, séance du 21 Juin 1943.

Audouin, J., and Poulain, J. (1950). Tuberculose sténosante de l'oesophage, d'apparence primitive, guérie par l'oesophagectomie. Arch. Mal. Appar. dig., 39, 231.

Baron, F., Venisse, C., and Legal, G. (1961). A propos d'un cas de tuberculose primitive de oesophage. Ann. Oto-laryng. (Paris), $78,142$.

Barrett, N. R. (1962). Benign stricture in the lower esophagus. $J$. thorac. cardiovasc. Surg., 43, 703. 
Bourdial, J., Lallemant, Y., Natali, R., and Lunel, J. (1963). Tuberculose de l'oesophage. Ann. Oto-laryng. (Paris), 80, 824.

Calvet, J., Coll, J., and Son-Qui (1961). Tuberculose de l'oesophage révélée par une paralysie récurentielle droite. Ibid., 78, 154.

Doesel, H. (1960). Im Röntgenbild verifizierte Ósophagusdivertikel bei Kindern und Jugendlichen mit Tuberkulose. Tuberk.-Arzt., $14,732$.

Gérard, A. (1964). Tuberculose de l'oesophage. Arch. Mal. Appar. dig., 53, 746.

Hawes, L. E. (1944). The roentgenological changes in the esophagus in tuberculous mediastinitis. Amer. J. Roentgenol., 51, 575.

Heimendinger, H., Fruhling, L., and Klotz, G. (1949). Tuberculose de l'oesophage développée sur une sténose cicatricielle préexistante et traitée par la streptomycine. Rev. Laryng. (Bordeaux), $70,459$.

Hlavacek, V. (1960). Deux de tuberculose de l'oesophage. Ann. Oto-laryng. (Paris), 77, 196.

Jeanne, E. (1948). Considérations nouvelles sur la tuberculose de l'oesophage traité par l'oesophagectomie. Thèse, Paris.

Kesztele, V. (1963). Ösophagustuberkulose. Wien. med. Wschr., 113, 430.

Kragh, J. (1922). Tuberculous diverticula of the oesophagus. Acta Oto-laryng. (Stockh.), 4, 49.

Lawson, J. F. (1949). Tuberculous esophago-cutaneous fistulae treated with streptomycin and gastrostomy. Amer. Rev. Tuberc., 59, 687.
Lüdin, M. (1947). Röntgenbefunde bei Oesophagustuberkulos Schweiz. Z. Tuberk., 4, 267.

Lunel, J., Natali, R., Chung-Seh-Tung, R. C. (1963). Tuberculog de l'oesophage d'allure primitive par fistule ganglio-oes phagienne. Genèse des diverticules oesophagiens épibronchiques
Arch. Mal. Appar. dig., 52, 530.

Maillet, P. (1960). Sténose oesophagienne consecutive au ma de Pott. Lyon chir., 56, 924.

Montandon, A. (1964). A propos de la tuberculose de l'oesophage Fistule ganglio-broncho-oesophagienne. Ann. Oto-laryng. (Paris? 81, 177.

Morichau-Beauchant, G., Coll, J., and Poussier, F. (1960). Sténose tuberculeuse de l'oesophage. Rev. Tuberc. (Paris), 24, 725.

Roget, J., Jaudel, J., Beaudoing, A., Valois, J., and Gilbert, $\bar{\omega}$ (1960). Hématémèse révélatrice d'un diverticule aortico-bronos chique de l'oesophage chez un enfant de 11 ans. Rôle probabler d'une fistulisation ganglionnaire tuberculeuse. Pédiatrie, 15 190.

Terracol, J., and Sweet, R. H. (1958). Diseases of the Esophagu p. 341. Saunders, Philadelphia.

Warembourg, H. Delacroix, R., Pauchant, M., and Sergent, (1959). (In French.) Oesophago-pleural fistula after pneum nectomy for tuberculosis. Arch. Mal. Appar. dig., 48, 1772.

Zoltán, I. (1943). Die Tuberkulose der Speiseröhre. Acta Oto-laryng (Stockh.), 31, 32. 